\title{
ИЗУЧЕНИЕ СРЕДНЕВЕКОВОГО БОЛЬШЕТАЯБИНСКОГО МОГИЛЬНИКА В 2018 Г.
}

\author{
(c) 2021 г. Н.С. Березина, А.Ю. Березин, И.Р. Газимзянов, Е.П. Михайлов, \\ Н.С. Мясников, Р.Н. Хамзин
}

Статья посвящена публикации новых материалов Большетаябинского могильника болгарской археологической культуры раскопок 2018 года, а также анализу материалов могильника раскопок 1948 г. (А.П. Смирнов) и 1984 г. (В.Ф. Каховский). Исследованные признаки позволяют говорить о мусульманском обряде погребения как господствующем, но отклонения от ортодоксальной мусульманской позы вместе с отсутствием железных гвоздей и скоб для крепления гвоздей, столь характерные для булгар второй половины домонгольского периода, позволяют предварительно сузить дату некрополя до X-XI вв. - первой половины домонгольской эпохи. Сравнительный анализ большетаябинской серии черепов отражает общие моменты расогенеза волжских булгар. В его основе лежат широкие метисационные процессы, проходившие между «местным» прикамско-приуральским населением (носителями, в основном, субуральского типа) и болгарскими или этнически близкие к ним племенами (носителями, в основном, более широколицего морфокомплекса).

Ключевые слова: археология, Чувашское Поволжье, Средневековье, Большетаябинский могильник, погребение, булгарская археологическая культура, антропологический анализ, краниометрия.

\section{STUDY OF BOLSHAYA TAYABA MEDIEVAL BURIAL GROUND IN 2018}

\section{N.S. Berezina, A.Yu. Berezin, I.R. Gazimzyanov, E.P. Mikhailov, N.S. Myasnikov, R.N. Khamzin}

The article is aimed at the publication of new materials from the Bolshaya Tayaba burial ground of the Bolgar archaeological culture of excavations in 2018, as well as the analysis of materials from the burial ground obtained at excavations in 1948 (A.P. Smirnov) and 1984 (V.F. Kakhovsky). The studied attributes suggest that the Muslim burial rite was predominant, but deviations from the orthodox Muslim posture, together with the absence of iron nails and staples for nail fastening, very characteristic of the Bolgars of the second half of the pre-Mongol period, allow to preliminarily narrow the dating of the necropolis to the $10^{\text {th }}-11^{\text {th }}$ centuries - the first half of the pre-Mongol period. A comparative analysis of the Bolshaya Tayaba series of skulls reflects the general aspects of the race genesis of the Volga Bolgars. It is based on wide miscegenation processes which occurred between the "local" Kama-Ural population (mainly carriers of the Sub-Ural type) and the Bolgarian or ethnically similar (mainly carriers of the broader-faced morphocomplex).

Keywords: archaeology, Chuvash Volga region, Middle Ages, Bolshaya Tayaba burial ground, burial, Bolgar archaeological culture, anthropological analysis, craniometry.

В 2018 году исследование Большетаябинского городища и могильника было возобновлено по инициативе чувашских археологов. Эти исследования были проведены совместно с татарскими коллегами в рамках плана исследований общего болгарского наследия. Была организована объединенная археологическая экспедиция Чувашского государственного института гуманитарных наук под руководством Михайлова Евгения Петровича и Института археологии им. А.Х. Халикова АН РТ под руководством Р.Н. Хамзина. Работы проводились в рамках Договора о научном сотрудничестве ЧГИГН и ИА АН РТ и по плану совместных научных экспедиций 2018-2020 гг. В работе совместной экспеди- ции принимали участие Н.С. Березина, А.Ю. Березин, Н.С. Мясников (ЧГИГН) и И.Р. Газимзянов (Казань).

Большетаябинский могильник - на сегодняшний день единственный известный булгарский некрополь на территории Чувашской Республики и один из немногих на территории правобережья Волги (Археологическая карта Чувашской Республики, т. 3. 2015, с. 247-248 (№ 2967)). Большетаябинский могильник входит в состав средневекового археологического комплекса «Большетаябинское городище», расположенного в Яльчикском районе Чувашской Республики, - одного из самых западных городов Волжской Булгарии (рис. 1: А-Б). Памятник располагается к запа- 

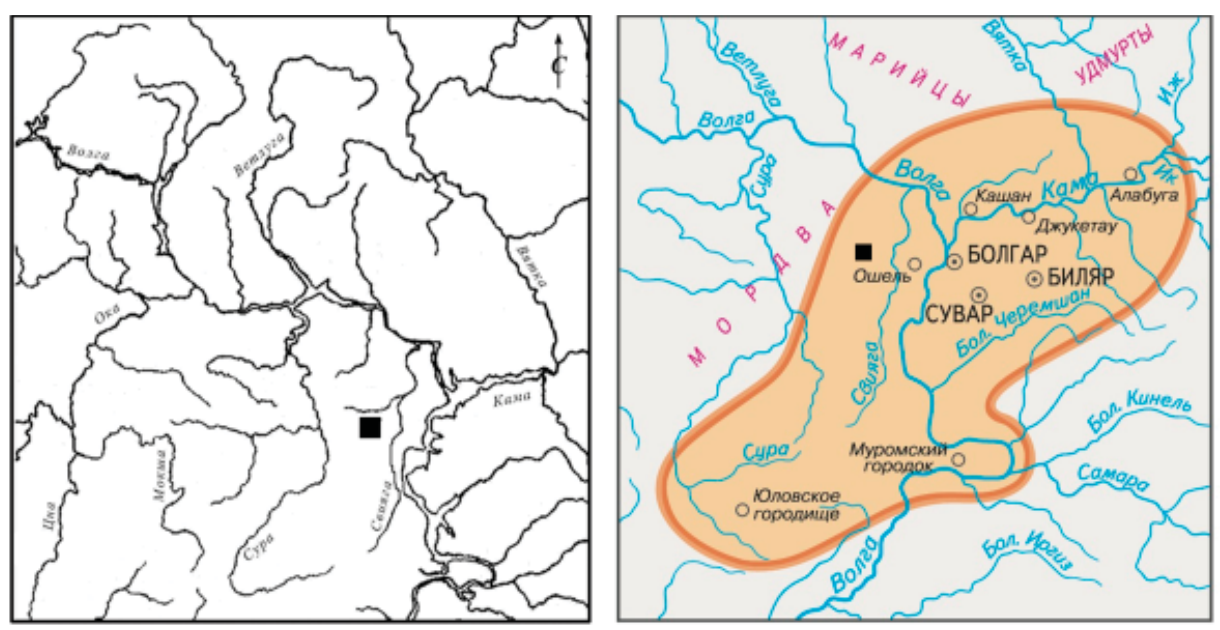

A

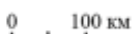

Б

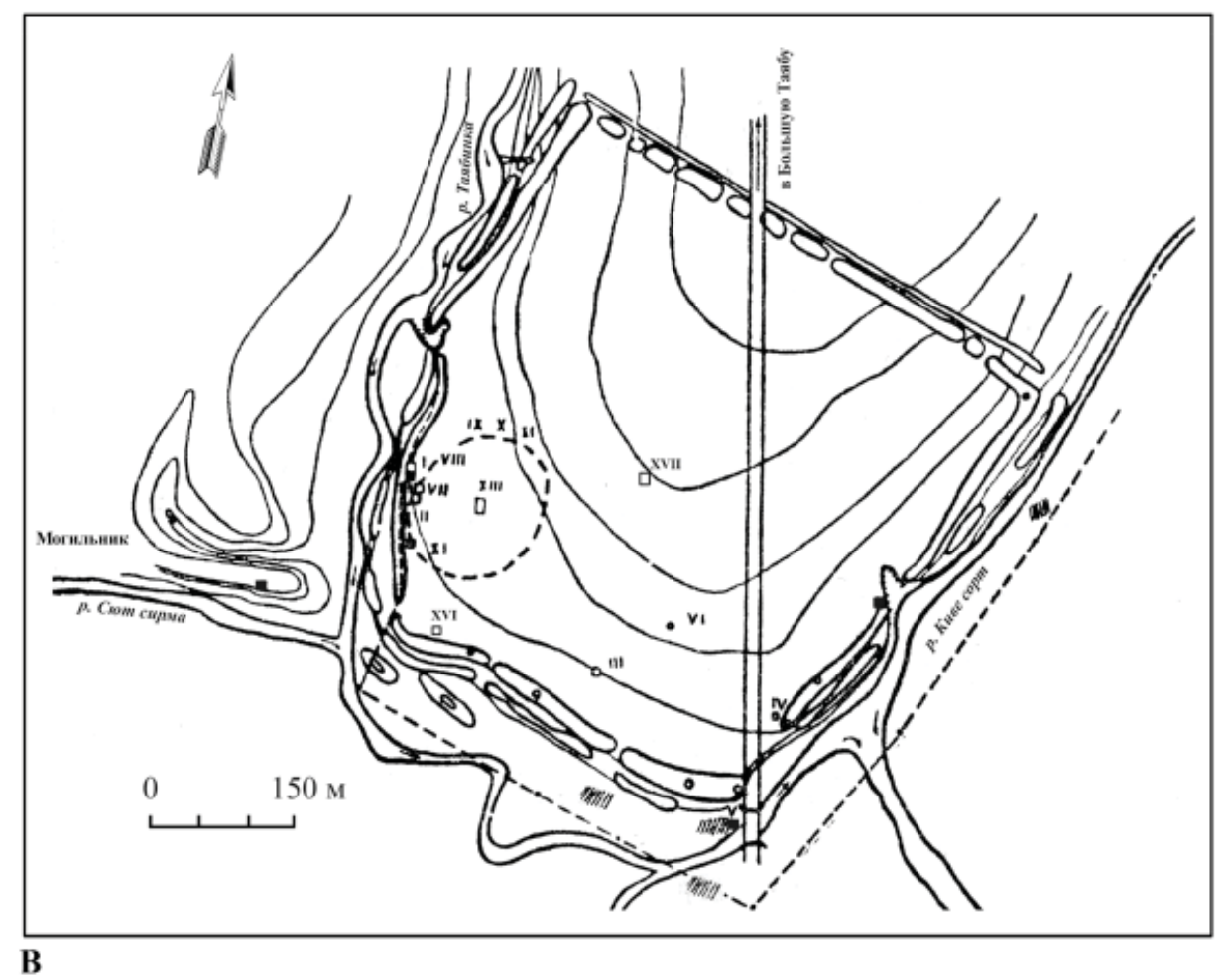

Рис. 1. Месторасположение Большетаябинского городища и могильника на контурной карте Среднего Поволжья

(А) и карте Волжской Булгарии X-XIII вв. (Б). Месторасположение могильника на топографическом плане городища Г.А. Федорова-Давыдова 1957 г. со сводным планом раскопов (В)

Fig. 1. Location of Bolshay Tayaba hillfort and burial ground on the contour map of the Middle Volga region (A) and the map of Volga Bolgaria of the $10^{\text {th }}-13^{\text {th }}$ centuries. (Б). Location of the burial ground on the topographic plan of the settlement by G.A. Fedorov-Davydov 1957 with a consolidated excavation plan (B)

ду от городища на противоположном к городищу правом берегу речки Таябинки, занимая мысовидный выступ размерами 30-80×185 м, образованный р. Таябинкой и р. Суу с̧ирми (рис. 1: В). В литературе могильник известен также под названиями «Сют-Сирми», «СютьСирьми».

История изучения. В 1948 г. памятник был открыт, описан и исследован экспедицией ЧНИИ ЯЛИ (рук. А.П. Смирнов). Место могильника с разрушающимися от эрозии берега погребениями было показано экспедиции местными жителями. В 1948 г. в заложен- ном раскопе площадью 24 кв. м было раскопано 16 погребений (рис. 2: Б). Из них 15 принадлежали «к одному типу: костяки положены головой на запад и большинство лицом на юг, руки лежали вытянуто вдоль тела или полусогнуты» (Смирнов, 1950, с. 146; Смирнов, 1961, с. 161). Лишь костяк в погребении 14 располагался головой на восток ${ }^{1}$

В северо-западном углу раскопа 1948 г. была обнаружена яма круглой формы (рис. 2: Б) (верхний диаметр 1,25 м), сужающаяся на глубину 42 см (нижний диаметр 83-90 см), которая имела следы сильного 


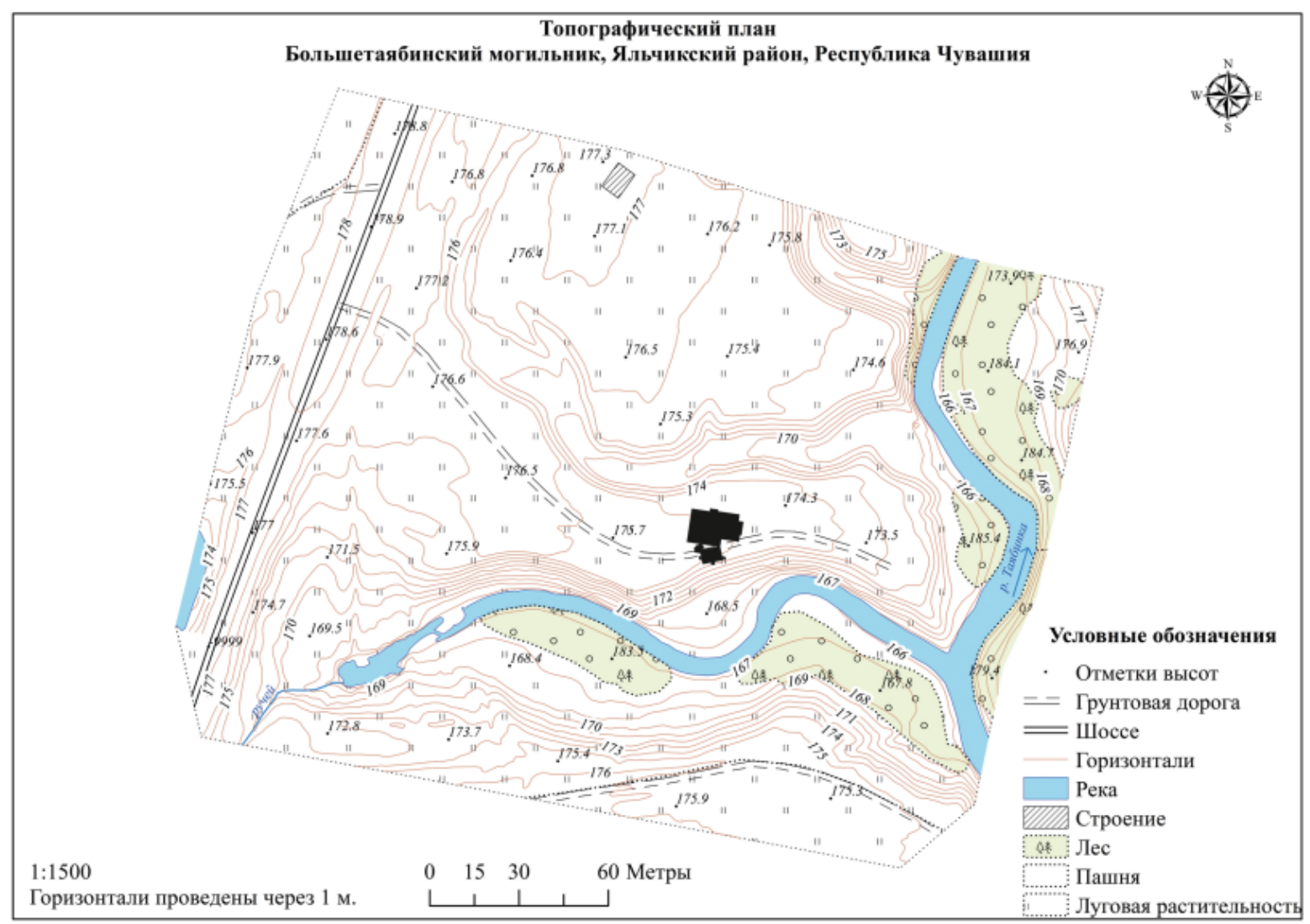

$\mathbf{A}$

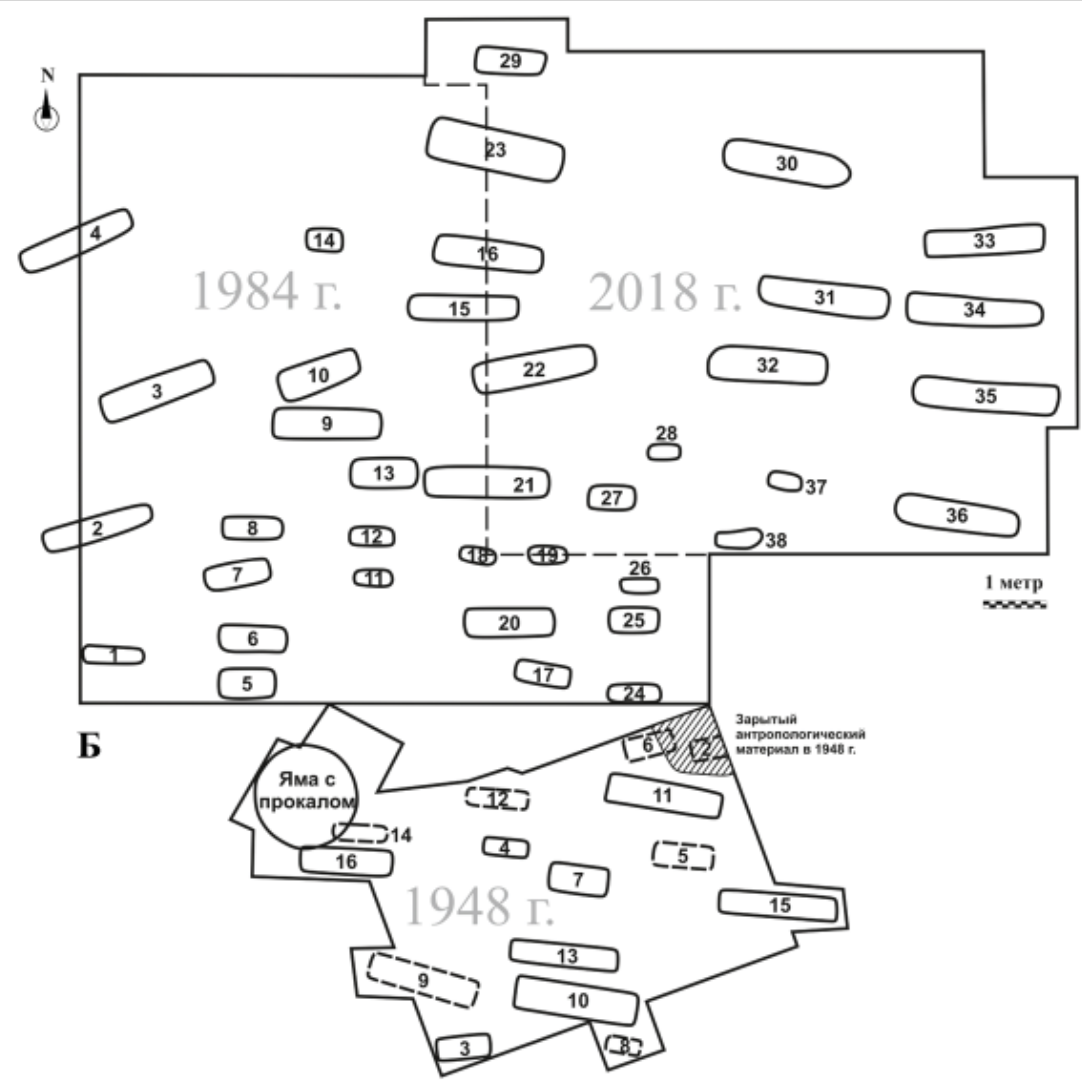

Pис. 2. Топографический план Большетаябинского могильника 2018 г. (сост. Беляев А.В., Вафина Г.Х., Овечкина Л.В.) со сводным планом всех раскопов (А). Сводный план раскопов на могильнике 1948, 1984 и 2018 г. (Б) Fig. 2. Topographic plan of the Bolshaya Tayaba burial ground of 2018 (compiled by Belyaev A.V., Vafina G.Kh., Ovechkina L.V.) with a summary plan of all excavations (A). Summary plan of excavations at the burial ground of 1948, 1984 and 2018. (Б) 
прокаливания. А.П. Смирнов отмечал, что в ней были найдены перемешанный с песком пепел, «включающий уголь и какие-то шлакообразные вещества от сгоревших органических остатков». Важно отметить, что в яме не было никаких следов костей. Яма была отнесена А.П. Смирновым ко времени функционирования изученного им участка могильника, т. к. была «впущена» с той же дневной поверхности, что и погребения. При этом яма перекрывала два захоронения, что по мнению А.П. Смирнова, говорило о несколько более позднем времени ее возникновения (Смирнов, 1950, с. 148; Смирнов, 1961, с. 162). Исследователь отмечал, что у чувашей известен поминальный обряд с разжиганием костров на кладбищах (Смирнов, 1950, с. 149; Смирнов, 1961, с. 163). Позднее эту идею поддержал Б.В. Каховский, который считал, что в яме зажигалось кострище во время похорон и могли совершаться языческие жертвоприношения. Он склонен связывать яму 1948 г. с культом огня в погребальном обряде волжских болгар (Каховский Б.В., 1985, с. 27)².

А.П. Смирнов относил Большетаябинский могильник к мусульманскому населению городища, не исключая и захоронения здесь жителей окружающих селищ (Смирнов, 1950, с. 148; Смирнов, 1961, с. 162) $)^{3}$. Он отмечал, что отсутствие погребального инвентаря не позволяет точно датировать вскрытую им часть могильника. «Единственным основанием» для датировки явилась находка «обломка болгарской посуды красно-желтого цвета, приготовленного на ручном гончарном круге, с гладкой поверхностью, как бы покрытой ангобом» в засыпи погребения 1 вне площади раскопа (Смирнов, 1950, с. 146-147; Смирнов, 1961, с. 161). А.П. Смирнов считал, что отсутствие погребального инвентаря ${ }^{4}$, ориентировка, глубина, форма могильных ям сближают Большетаябинский могильник с мусульманскими кладбищами болгарских городов золотоордынского времени (Смирнов, 1950, с. 148; Смирнов, 1961, с. 162). В дальнейшем эта условная датировка памятника золотоордынским периодом в целом утвердилась (Фахрутдинов, 1971, с. 180, 193, рис. III), хотя некоторые ученые считали некрополь домонгольским (Акимова, 1955, с. 82; Краснов, 1974, с. 121). В совместной публикации В.Ф. Каховского и А.П. Смирнова авторы отмечали, что могильник мог функционировать и в домонгольское, и в золотоордынское время (Каховский В.Ф., Смирнов, 1972, c. 121).
Палеоантропологическое изучение материалов некрополя проводила в нач. 1950-х гг. М.С. Акимова. Она проанализировала три мужских (погребения 9, 10, 11) и три женских (погребения 13, 15 и без №) черепа из Большетаябинского могильника (у нее: «СютьСирьми) (Акимова, 1955, с. 82, 84, 85-86 (табл. 2)). М.С. Акимова отметила, что эти черепа имеют небольшие размеры продольного и поперечного диаметров, по указателю мезо-брахикранны. «Лоб слабо наклонный, со слабо развитым надбровьем. Лицо невысокое и узкое, с неглубокой клыковой ямкой и слабо выступающим носом. На двух черепах отмечается также некоторая уплощенность лица» (Акимова, 1955, с. 82). Как известно, М.С. Акимова в 1949-1950 гг. проводила раскопки могильников XVI-XVIII вв. на территории Чувашской и Марийской АССР. Она пыталась соотносить палеоантропологические материалы Большетаябинского могильника с более поздними чувашскими и марийскими материалами. Она пишет, что все изученные ею 6 черепов с «Сют-Сирми» относятся «скорее к субуральскому типу и близки к марийским черепам XVII-XVIII вв. и к женским черепам с территории Южной Чувашии 5 . От остальных чувашских черепов они резко отличаются небольшими размерами лица, слабо развитым рельефом, общей грацильностью, меньшим продольным диаметром» (Акимова, 1955, с. 82)

В 1984 г. раскопки могильника были продолжены Чувашской археологической экспедицией (рук. Б.В. Каховский и В.Ф. Каховский). Раскоп 1 размерами $10 \times 10$ м был заложен к северу от раскопок 1948 г. ${ }^{7}$ На этой площади было вскрыто 28 погребений (рис. 2: Б). Все костяки оказались ориентированы головой на запад. В кв. 5 после снятия первого штыка был найден «фрагмент булгарской керамики желтого цвета, с лощеной поверхностью» (Каховский Б.В., 1985, с. 27). По мнению Б.В. Каховского, исследования 1984 г. позволяют выделить здесь два обряда погребения. Большинство захоронений, главным образом женских (3) и детских (8), он отнес к мусульманским. Для них характерно отсутствие погребального инвентаря, «тело либо слегка повернуто на правый бок, либо лицо обращено к югу», но отсутствуют боковой подбой, ямы неглубокие (Каховский Б.В., 1985, с. 29). Выделяемый второй обряд, на взгляд Б.В. Каховского, характерен для некоторых (4) погребений мужчин, совершенных «с соблюдением языческих традиций волжских болгар: положение костяка вытянутое, голо- 
Большетаябинский могильник - 2018 г.

Сводный план раскопа и профиль восточной стенки до прирезки

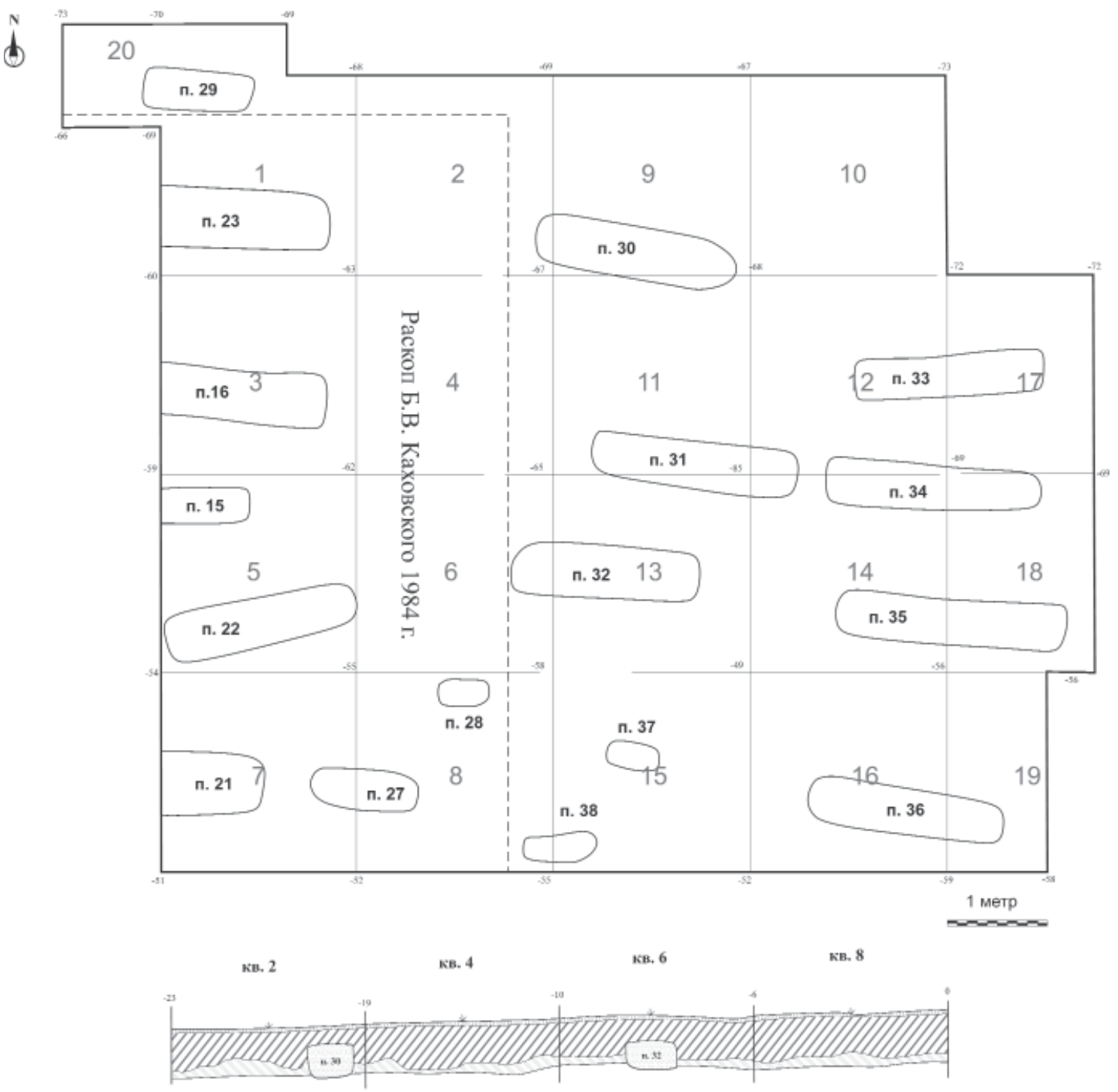

Условные обозначения:

- дерн
- темно-серая гумусированная супесь
(черноземная почва)

- пестроцветный слой (перемешанный слой гумуса и коричневого суглинка)

- коричневый суглинок

Рис. 3. План раскопа 2018 г. и профиль восточной стенки раскопа (кв. 2-8) до прирезки

Fig. 3. Excavation plan of 2018 and a profile of the eastern wall of the excavation (squares 2-8) before expansion of the excavation area

вой на запад, лицом кверху» (Каховский Б.В., и 1984 гг. отметил, что «выявленные особенно1985, с. 29). В публикации 1992 г. Б.В. Каховский и В.Ф. Каховский пишут категоричнее: «Большинство захоронений, главным образом женские и детские, совершены по мусульманскому обряду. Погребения мужчин выполнены с соблюдением языческих традиций. Смена религиозных представлений и обрядов происходила, видимо, в XIV в., когда функционировало городище» (Каховский Б.В., Каховский В.Ф., 1992, с. 76). В более поздней статье (1995 сти погребального обряда свидетельствуют, по всей вероятности, о бытовании среди населения городища людей с языческим воззрением и мусульманского верования» (Каховский В.Ф., 1995, c. 16).

\section{Археологические работы 2018 г.}

Раскоп 2018 г. был заложен в восточной части могильника с целью продолжить раскоп Б.В. Каховского, исходя из сведений отчета 1984 г. и воспоминаний участника раскопок г.) В.Ф. Каховский на основе материалов 1948

1984 г. Е.П. Михайлова (рис. 2). Раскопом 
общей площадью 73,65 кв. м. был затронут раскоп и часть погребений 1984 г., что позволило вписать раскоп 2018 г. в общий план раскопов.

Планиграфия и стратиграфия раскопа на Большетаябинском могильнике 2018 г. проста (рис. 3). Практически повсеместно под слоем дерна мощностью 5-10 см находился слой почвы в виде темно-серой гумусированной супеси (чернозем) мощностью 30-50 см. Каких-либо следов подрезания, перемешивания, плужной вспашки зафиксировано не было. По всей видимости, могильный мыс не подвергался распашке в прошлом. На участках южной стенки на кв. 7-8, в западной стенке раскопа, южной и частично западной стенках кв. 20 сразу под дерном фиксировался перемешанный слой темно-серой гумусированной супеси (чернозема) с включениями коричневого материкового суглинка - засыпанный раскоп Б.В. Каховского 1984 г. Также в восточной стенке кв. 2, 4, 6, 8, зачищенной до прирезки кв. 9-16, было зафиксировано два погребения (пятна корытообразного профиля шириной ок. 40-50 см) в кв. 2 и 6 (пп. 30, 32). Заполнение погребений, зафиксированных в стенках и на пластовых зачистках, представляло собой перемешанный слой, состоящий из темно-серой гумусированной супеси (чернозема) с включениями коричневого материкового суглинка. Глубина фиксации погребений - ок. 20-25 см от современной поверхности, что соответствует, видимо, дневной поверхности X-XIII вв. Ниже слоя почвы и перекопанного раскопа 1984 г. на глубине ок. 50-65 см повсеместно фиксировался подстилающий (материковый) слой коричневого суглинка.

В 2018 г. на могильнике было выявлено 7 изученных Б.В. Каховским в 1984 г. погребений. Из данных захоронений был извлечен пригодный для антропологического определения материал. В остальной части раскопа было исследовано 10 погребений (4 детских костяка, в т. ч. один во взрослом погребении и 7 взрослых) (рис. 4-6). В общей сложности за все годы исследования на Большетаябинском могильнике археологически изучено частично или полностью 54 погребения.

Погребальный обряд. Мы попытались представить общие характеристики погребального обряда Большетаябинского некрополя за все годы раскопок ${ }^{8}$ (табл. 1). Топография могильника характеризуется его расположением за естественной преградой -рекой, отделяющей его от городища, и расположением некрополя на мысовидном выступе, образованном двумя оврагами. Следов культурного слоя, за исключением отдельных (двух) фрагментов керамики, обнаружено не было, что говорит о том, что это место изначально было выделено под кладбище. Могилы образовывали нестройные ряды, вытянутые меридионально (по линии север - юг) поперек площадки могильного мыса. Говорить о выделении каких-то групп, в частности семейных, судя по имеющемуся сводному плану (рис. 2: Б), вряд ли правомерно. Можно отметить несколько чрезмерную концентрацию детских захоронений в центральной части раскопанной площади. Следов столбов или иных надгробий обнаружено не было. Вероятно, могилы выделялись на местности небольшими земляными холмиками. Во всяком случае, не зафиксировано ни одного случая перекрывания могильных ям друг другом.

Все могилы имели простую форму: вытянутые подпрямоугольные очертания с закругленными углами. Длина могильных ям довольно стандартна: 170-200 см у взрослых индивидов (максимально до 230 см). Отметим некоторую узость могильных ям: ширина 30-50 (максимум до 60 см), ширина многих могильных ям была достаточной лишь для укладывания тела. В некоторых случаях (пп. 30, 32, 33, 35, 362018 г.) в могилах со взрослыми индивидами южная длинная стенка была слегка скошена во внешнюю сторону. Еще в ряде случаев (пп. 32, 34, 35, 36 2018 г.) с южной стороны могилы фиксировалась небольшая ступенька-уступчик. Наиболее сложен вопрос о наличии гробов в погребениях. Дерево в местных условиях не сохраняется. Железных гвоздей или скоб зафиксировано не было. При этом во время раскопок 1948 или 1984 г. не оставлялись контрольные стенки для фиксации особенностей заполнения могильных ям. В 2018 г. такие стенки оставлялись в области ног умерших, что позволило достоверно зафиксировать гробовища (или рамную конструкцию) в погребениях 30 и 36 . Однако в целом наличие гробов скорее нехарактерно для погребального обряда Большетаябиснкого могильника, а вышеотмеченная узость могильных ям такова, что для гроба в них просто не будет места.

Все погребения индивидуальные, лишь в одной могиле (п. 31) в изголовье рядом с погребенной женщиной (?) были захоронены кости младенца (новорожденного?). Ориентация костяков достаточно выдержана: одно погребение было ориентировано на восток, два на 
Большетаябинский могильник-2018

Погребение № 29

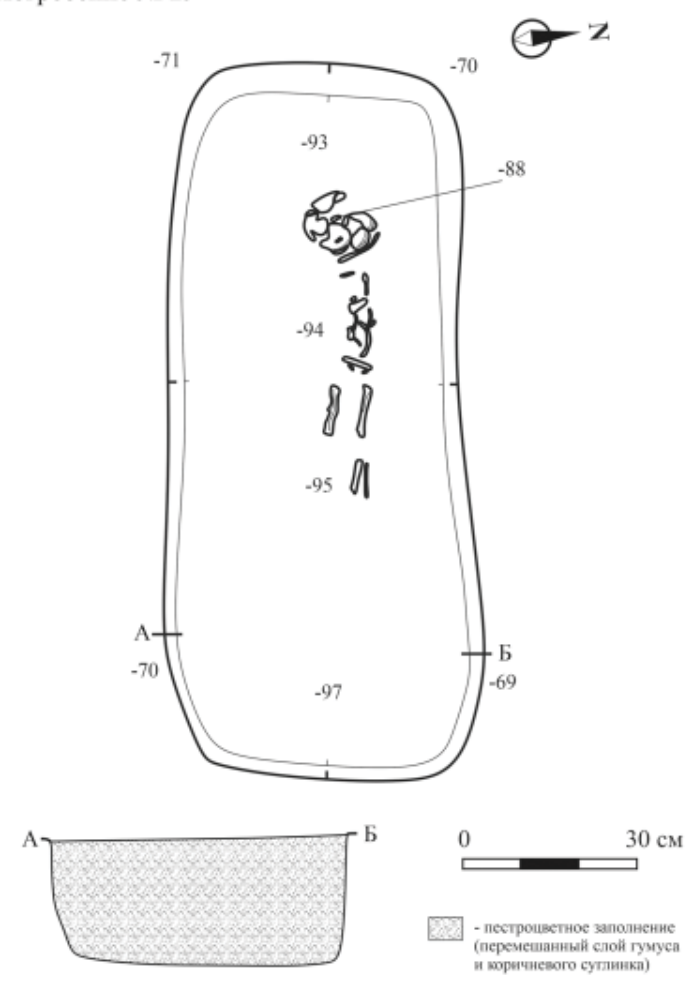

Большетаябинский могильник-2018

Погребение № 31

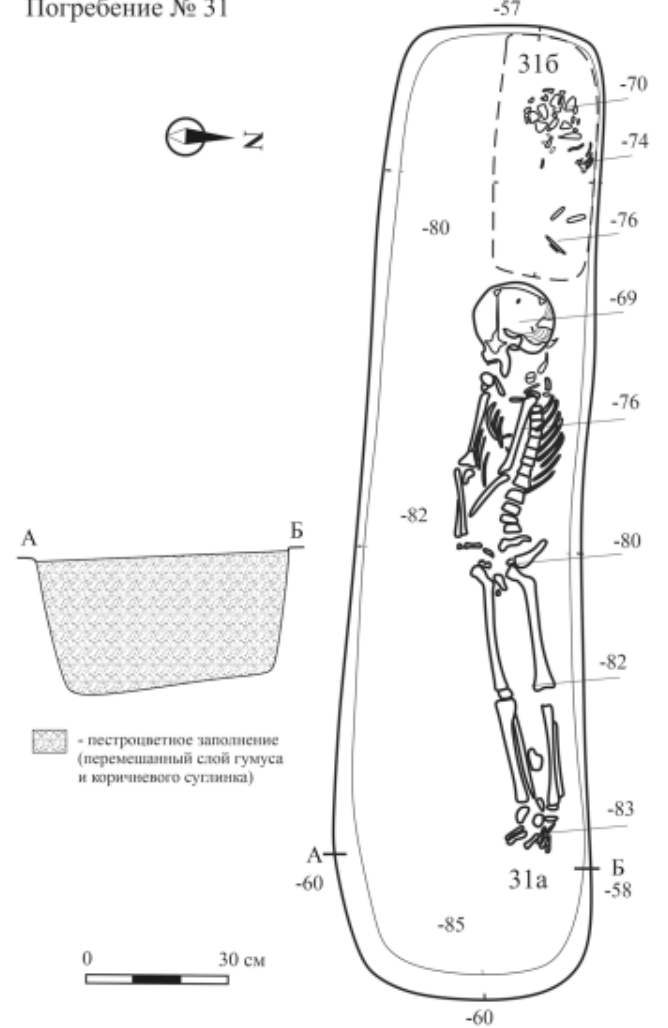

Большетаябинский могильник-2018

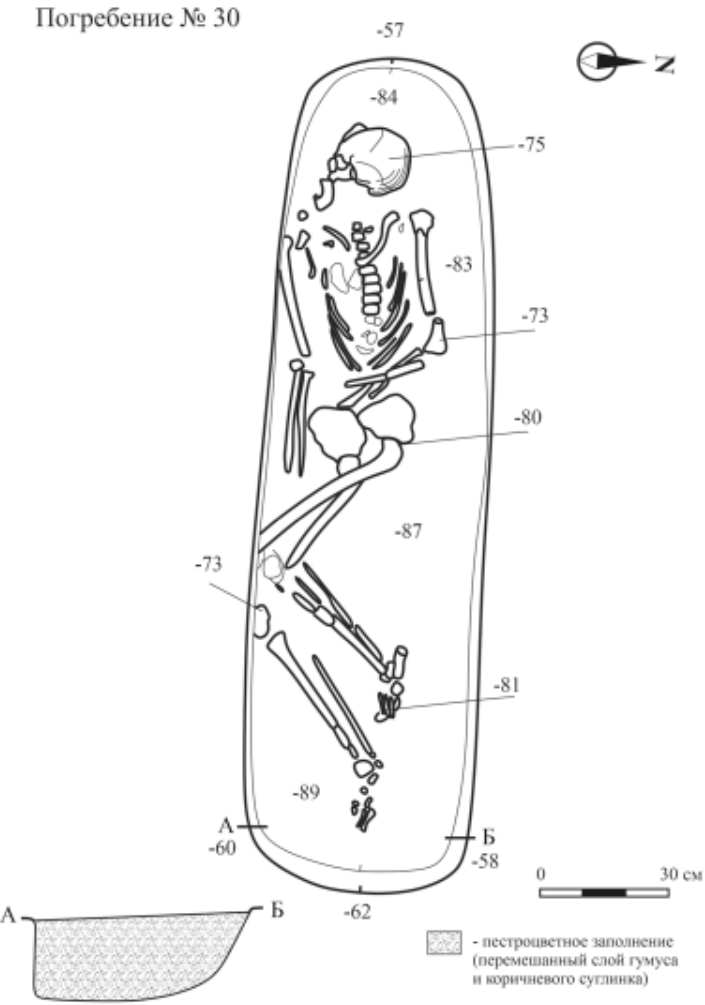

Большетаябинский могильник-2018 Погребение № 32

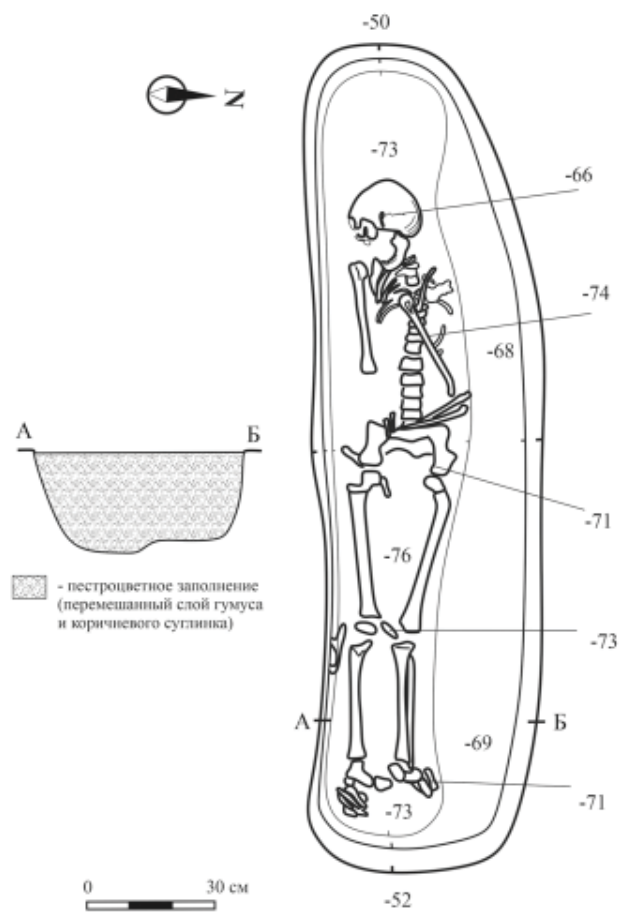

Рис. 4. Планы погребений 29-32 раскопа 2018 г.

Fig. 4. Plans of burials 29-32 at the excavation of 2018

юго-запад (аз. 225-245), остальные 51 погребение - на запад (аз. 250-283). Для могильника в целом характерна устойчивая поза захороненных, при незначительных отклонениях. В большинстве прослеженных случаях лицо погребенного было повернуто на юг (34 п.) (83\% определимых случаев); в шести случаях было зафиксировано положение лицом вверх и в одном - на север. Для погребенных была характерна поза с правой рукой, вытяну- 
той вдоль туловища, и согнутой и лежащей в области таза левой (27 п.) (75\% определимых случаев), однако отмечены и случаи с руками вдоль корпуса (5 п.) и полусогнутыми на тазу (4 п.). При наиболее характерном положении рук, как правило, наблюдается легкий поворот туловища в правый бок. Однако в 1948 г. и 1984 г. исследователи не вдавались в тонкости подобной позы и отмечали, что большинство погребенных было уложено на спину. Судя по сохранившимся планам и фотографиям, можно говорить о положении на спине у 24, а с легким поворотом на правый бок у 13 погребенных ${ }^{9}$. Погребальный инвентарь полностью отсутствовал.

Указанные признаки позволяют говорить о мусульманском обряде погребения как господствующем на Большетаябинском могильнике. К нему относится обязательное положение покойника головой на запад (с легким отклонением к северу), лицом на юг (к Мекке) с поворотом туловища на правый бок. Правая рука при таком положении обычно вытянута, левая согнута и расположена на правой стороне таза. Характерной чертой является полное отсутствие сопровождающих вещей, кроме савана. Тело усопшего должно быть изолировано от земли (подбой-ляхд, гроб, перекрытие) (Халикова, 1986, с. 46-48; Яблонский, 1987). Вместе с тем мы видим на Большетябинском некрополе некоторые достаточно устойчивые отклонения от ортодоксальных требований ислама, в первую очередь относительно положения лица и рук погребенных и отсутствия гробов в большинстве могил. Также важной особенностью является вероятное разжигание поминальных костров на кладбище, зафиксированное ямой с прокалом в раскопе 1948 г. и, возможно, в обрыве берега в 1992 г. Однако вряд ли на этом основании правомер- но говорить о языческом обряде погребения части населения городища. Скорее о неустойчивости мусульманского обряда и его отдельных особенностях. Выводы Б.В. Каховского и В.Ф. Каховского о религиозной дифференциации жителей городища по полу, на наш взгляд, не подтверждаются.

Некрополь, несомненно, являлся одним из городских кладбищ Большетаябинского городища. Время функционирования могильника, по нашему мнению, нуждается в существенной корректировке. Его отнесение к XIII или даже XIV в. было связано с определением верхней даты существования городища началом ордынской эпохи. Однако раскопки городища 2018-2019 гг., как и пересмотр археологических коллекций раскопок 1948 г. (А.П. Смирнов) и 1957 г. (Г.А. Федоров-Давыдов), хранящихся в Чувашском национальном музее, не выявили материалов с территории городища, выходящих за хронологический рубеж X - начала XIII вв. (Михайлов, 2018, с. $86,99)$. Таким образом, широкая дата существования некрополя может быть определена домонгольским периодом. Однако, как нам представляется, вышеуказанные отклонения от ортодоксальной мусульманской позы вместе с отсутствием железных гвоздей и скоб для крепления гвоздей, столь характерные для булгар второй половины домонгольского периода (Халикова, 1986, с. 99-100, 105), позволяют предварительно сузить дату некрополя до X-XI вв. - первой половины домонгольской эпохи.

Антропологический анализ. Немногочисленные антропологические материалы из раскопок А.П. Смирнова, как уже было отмечено выше, по краниологической программе исследовала М.С. Акимова. На основе краниометрических данных по трем мужским и

Таблища 1. Размеры, ориентировка погребений и положение погребенных

Table 1. Dimensions and orientation of burials, and position of the buried individuals

\begin{tabular}{|c|c|c|c|c|c|c|c|}
\hline \multirow[t]{2}{*}{ № погребения } & \multicolumn{3}{|c|}{ Размеры погребений } & \multirow{2}{*}{$\begin{array}{c}\text { Ориентировка } \\
\text { головы } \\
\text { (азимут) }\end{array}$} & \multicolumn{3}{|c|}{ Положение погребенных } \\
\hline & $\begin{array}{c}\text { Длина } \\
\text { (см) }\end{array}$ & $\begin{array}{c}\text { Ширина } \\
\text { (см) }\end{array}$ & $\begin{array}{c}\text { Глубина } \\
\text { (см от } \\
\text { поверх- } \\
\text { ности) }\end{array}$ & & $\begin{array}{c}\text { Положение } \\
\text { лица }\end{array}$ & $\begin{array}{c}\text { Положение } \\
\text { рук }\end{array}$ & $\begin{array}{c}\text { Положение } \\
\text { корпуса }\end{array}$ \\
\hline $\begin{array}{l}\text { Погребение } 1 \\
\text { (раскопки А.П. } \\
\text { Смирнова, 1948) }\end{array}$ & - & - & 60 & запад & прямо & полусогнуты & на спине \\
\hline Погребение 2 & - & 35 & 28 & $260^{\circ}$ & ЮГ & - & на спине \\
\hline Погребение 3 & 90 & 40 & 50 & $260^{\circ}$ & прямо & - & на спине \\
\hline Погребение 4 & 75 & 30 & 50 & $275^{\circ}$ & ЮГ & полусогнуты & на спине \\
\hline Погребение 5 & 95 & 35 & 40 & $270^{\circ}$ & прямо & Вытянуты & на спине \\
\hline Погребение 6 & 80 & 35 & 40 & $253^{\circ}$ & ЮГ & вытянуты & на спине \\
\hline Погребение 7 & 95 & 45 & 43 & $274^{\circ}$ & ЮГ & вытянуты & на спине \\
\hline Погребение 8 & 60 & 30 & 60 & $278^{\circ}$ & ЮГ & вытянуты & на спине \\
\hline Погребение 9 & 175 & 50 & 70 & $283^{\circ}$ & ЮГ & вытянуты & на спине \\
\hline
\end{tabular}




\begin{tabular}{|c|c|c|c|c|c|c|c|}
\hline Погребение 10 & 195 & 55 & 70 & $275^{\circ}$ & ЮГ & $\begin{array}{l}\text { правая вдоль, } \\
\text { левая на тазу }\end{array}$ & на спине \\
\hline Погребение 11 & 180 & 40 & 70 & $277^{\circ}$ & ЮГ & $\begin{array}{l}\text { правая вдоль, } \\
\text { левая на тазу }\end{array}$ & на спине \\
\hline Погребение 12 & 100 & 30 & 61 & $272^{\circ}$ & ЮГ & $\begin{array}{l}\text { правая вдоль, } \\
\text { левая на тазу }\end{array}$ & на спине \\
\hline Погребение 13 & 170 & 40 & 82 & $272^{\circ}$ & ЮГ & $\begin{array}{l}\text { правая вдоль, } \\
\text { левая на тазу }\end{array}$ & на спине \\
\hline Погребение 14 & 90 & 30 & 62 & $90^{\circ}$ & ЮГ & $\begin{array}{l}\text { правая вдоль, } \\
\text { левая на тазу }\end{array}$ & на спине \\
\hline Погребение 15 & 190 & 40 & 80 & $270^{\circ}$ & ЮГ & полусогнуты & на спине \\
\hline Погребение 16 & 150 & 40 & 78 & $270^{\circ}$ & ЮГ & $\begin{array}{l}\text { правая вдоль, } \\
\text { левая на тазу }\end{array}$ & на спине \\
\hline $\begin{array}{l}\text { Погребение 1 } \\
\text { (раскопки Б.В. } \\
\text { Каховского, } \\
1984 \text { ) } \\
\end{array}$ & 97 & 32 & 49 & $270^{\circ}$ & - & $\begin{array}{l}\text { правая вдоль, } \\
\text { левая на тазу }\end{array}$ & $\begin{array}{c}\text { легкий } \\
\text { поворот } \\
\text { правый бок }\end{array}$ \\
\hline Погребение 2 & 185 & 31 & 48 & $225^{\circ}$ & прямо & $\begin{array}{l}\text { правая вдоль, } \\
\text { левая на тазу }\end{array}$ & на спине \\
\hline Погребение 3 & 190 & 48 & 48 & $250^{\circ}$ & ЮГ & $\begin{array}{l}\text { правая вдоль, } \\
\text { левая на тазу }\end{array}$ & на спине \\
\hline Погребение 4 & 200 & 44 & 50 & $245^{\circ}$ & прямо & $\begin{array}{l}\text { правая вдоль, } \\
\text { левая на тазу }\end{array}$ & на спине \\
\hline Погребение 5 & 100 & 50 & 55 & $270^{\circ}$ & ЮГ & - & - \\
\hline Погребение 6 & 112 & 40 & 50 & $270^{\circ}$ & ЮГ & - & - \\
\hline Погребение 7 & 108 & 40 & 34 & $260^{\circ}$ & ЮГ & $\begin{array}{l}\text { правая вдоль, } \\
\text { левая на тазу }\end{array}$ & $\begin{array}{c}\text { легкий } \\
\text { поворот } \\
\text { правый бок } \\
\end{array}$ \\
\hline Погребение 8 & 100 & 38 & 44 & $270^{\circ}$ & ЮГ & - & - \\
\hline Погребение 9 & 177 & 45 & 57 & $270^{\circ}$ & ЮГ & $\begin{array}{l}\text { правая вдоль, } \\
\text { левая на тазу }\end{array}$ & $\begin{array}{c}\text { легкий } \\
\text { поворот } \\
\text { правый бок } \\
\end{array}$ \\
\hline Погребение 10 & 135 & 50 & 53 & $250^{\circ}$ & ЮГ & $\begin{array}{l}\text { правая вдоль, } \\
\text { левая на тазу }\end{array}$ & $\begin{array}{c}\text { легкий } \\
\text { поворот } \\
\text { правый бок }\end{array}$ \\
\hline Погребение 11 & 60 & 25 & 42 & $270^{\circ}$ & ЮГ & $\begin{array}{l}\text { правая вдоль, } \\
\text { левая на тазу }\end{array}$ & $\begin{array}{c}\text { легкий } \\
\text { поворот } \\
\text { правый бок }\end{array}$ \\
\hline Погребение 12 & 78 & 30 & 45 & $270^{\circ}$ & - & полусогнуты & на спине \\
\hline Погребение 13 & 120 & 50 & 53 & $270^{\circ}$ & ЮГ & - & - \\
\hline Погребение 14 & 60 & 38 & 50 & $270^{\circ}$ & ЮГ & - & - \\
\hline Погребение 15 & 180 & 40 & 49 & $270^{\circ}$ & север & $\begin{array}{l}\text { правая вдоль, } \\
\text { левая на тазу }\end{array}$ & на спине \\
\hline Погребение 16 & 180 & 50 & 51 & $275^{\circ}$ & ЮГ & $\begin{array}{l}\text { правая вдоль, } \\
\text { левая на тазу }\end{array}$ & на спине \\
\hline Погребение 17 & 85 & 42 & 56 & $275^{\circ}$ & - & - & - \\
\hline Погребение 18 & 62 & 25 & 39 & $275^{\circ}$ & - & - & - \\
\hline Погребение 19 & 53 & 31 & 54 & $270^{\circ}$ & - & - & - \\
\hline Погребение 20 & 145 & 47 & 54 & $270^{\circ}$ & ЮГ & $\begin{array}{l}\text { правая вдоль, } \\
\text { левая на тазу }\end{array}$ & $\begin{array}{c}\text { легкий } \\
\text { поворот } \\
\text { правый бок } \\
\end{array}$ \\
\hline Погребение 21 & 204 & 50 & 58 & $270^{\circ}$ & ЮГ & $\begin{array}{l}\text { правая вдоль, } \\
\text { левая на тазу }\end{array}$ & $\begin{array}{c}\text { легкий } \\
\text { поворот } \\
\text { правый бок } \\
\end{array}$ \\
\hline Погребение 22 & 200 & 48 & 57 & $260^{\circ}$ & ЮГ & $\begin{array}{l}\text { правая вдоль, } \\
\text { левая на тазу }\end{array}$ & $\begin{array}{c}\text { легкий } \\
\text { поворот } \\
\text { правый бок }\end{array}$ \\
\hline Погребение 23 & 225 & 58 & 70 & $280^{\circ}$ & ЮГ & $\begin{array}{l}\text { правая вдоль, } \\
\text { левая на тазу }\end{array}$ & $\begin{array}{c}\text { легкий } \\
\text { поворот } \\
\text { правый бок }\end{array}$ \\
\hline Погребение 24 & 78 & 25 & 48 & $270^{\circ}$ & - & - & - \\
\hline Погребение 25 & 85 & 35 & 45 & $270^{\circ}$ & - & - & - \\
\hline Погребение 26 & 64 & 23 & 42 & $270^{\circ}$ & - & - & - \\
\hline Погребение 27 & 32 & 36 & 43 & $270^{\circ}$ & - & - & - \\
\hline Погребение 28 & 52 & 22 & 45 & $270^{\circ}$ & - & - & - \\
\hline $\begin{array}{l}\text { Погребение } 29 \\
\text { (раскопки Е.П. } \\
\text { Михайлова, } \\
\text { 2018) } \\
\end{array}$ & 120 & 60 & 75 & $278^{\circ}$ & - & - & - \\
\hline Погребение 30 & 195 & 60 & 70 & $271^{\circ}$ & ЮГ & $\begin{array}{l}\text { правая вдоль, } \\
\text { левая на тазу }\end{array}$ & правый бок \\
\hline
\end{tabular}




\begin{tabular}{|c|c|c|c|c|c|c|c|}
\hline Погребение 31 & 210 & 55 & 70 & $270^{\circ}$ & ЮГ & $\begin{array}{l}\text { правая вдоль, } \\
\text { левая на тазу }\end{array}$ & $\begin{array}{c}\text { легкий } \\
\text { поворот } \\
\text { правый бок }\end{array}$ \\
\hline Погребение 32 & 195 & 55 & 65 & $265^{\circ}$ & юГ & $\begin{array}{l}\text { правая вдоль, } \\
\text { левая на тазу }\end{array}$ & $\begin{array}{c}\text { легкий } \\
\text { поворот } \\
\text { правый бок }\end{array}$ \\
\hline Погребение 33 & 200 & 45 & 68 & $274^{\circ}$ & юГ & $\begin{array}{l}\text { правая вдоль, } \\
\text { левая на тазу }\end{array}$ & на спине \\
\hline Погребение 34 & 200 & 50 & 90 & $268^{\circ}$ & ЮГ & $\begin{array}{l}\text { правая вдоль, } \\
\text { левая на тазу }\end{array}$ & на спине \\
\hline Погребение 35 & 230 & 55 & 90 & $270^{\circ}$ & ЮГ & $\begin{array}{l}\text { правая вдоль, } \\
\text { левая на тазу }\end{array}$ & $\begin{array}{c}\text { легкий } \\
\text { поворот } \\
\text { правый бок }\end{array}$ \\
\hline Погребение 36 & 190 & 45 & 85 & $270^{\circ}$ & прямо & $\begin{array}{l}\text { правая вдоль, } \\
\text { левая на тазу }\end{array}$ & $\begin{array}{c}\text { легкий } \\
\text { поворот } \\
\text { правый бок }\end{array}$ \\
\hline Погребение 37 & 60 & 30 & 40 & $282^{\circ}$ & - & - & - \\
\hline Погребение 38 & 67 & 20 & 55 & $274^{\circ}$ & - & - & - \\
\hline
\end{tabular}

трем женским черепам она сделала предварительный вывод о том, что черепа относятся к «местному» субуральскому типу - узкое и низкое лицо сочетается с некоторой его уплощенностью и небольшим углом выступания носа (Акимова, 1955). Полученные в 2018 г. новые краниологические материалы, частично реставрированные и пригодные к измерениям, состояли из четырех мужских и четырех женских черепов. Таким образом, большетаябинская серия ненамного, но увеличилась, что позволяет более объективно оценить не только морфологический состав жителей средневекового булгарского города, но и всего населения Предволжья этого времени. При этом надо учитывать, что на сегодняшний день мы имеем лишь данные по небольшой серии черепов из раннемусульманского Тетюшского могильника (X-XII вв.), опубликованные в монографии С.Г. Ефимовой (Ефимова, 1991), и краниометрические сведения по двум мужским черепам из более позднего мусульманского некрополя, выявленного в 2003 году А.А. Бурхановым на территории Тетюшского I городища (Бурханов и др., 2003; Газимзянов, 2003).

Мужские черепа Большетаябинского могильника суммарно характеризуются средними параметрами черепной коробки, среднешироким и средненаклонным лбом с умеренно развитым мышечным рельефом (табл. 2). Лицевой скелет также средних размеров и средних пропорций. Исключение - низкие и относительно широкие орбиты. В вертикальной проекции серия ортогнатна, а в горизонтальной - хорошо профилирована. Переносье средней высоты и несколько уплощенное. Угол выступания носа на границе малых и средних значений. Клыковая ямка средней глубины, нижний край грушевидного отверстия в половине случаев имеет заостренные края. Из приведенных обобщенных характеристик можно сделать вывод о том, что мужские черепа в целом характеризуются европеоидными чертами мезоморфного типа. Отмечается небольшая монголоидная примесь, связанная прежде всего с ослабленным выступанием носовых костей.

Женские черепа, с учетом полового диморфизма, мало чем отличались по морфологическому типу от мужских. Вместе с тем на их фоне они выглядели более грацильными и более уплощенными как на уровне орбит, так и на уровне скуловых дуг. То есть на женских черепах монголоидные черты выражены более отчетливо. В итоге антропологическая характеристика большетаябинских черепов, данная М.С. Акимовой, находит некоторое подтверждение и в новых материалах. Скорее всего, генезис антропологического типа населения, оставившего Большетаябинский некрополь, связан с местным (в широком значении этого слова) прикамско-приуральским населением. Однако рассмотрение индивидуальных данных не позволяет говорить об этом в категоричной форме (табл. 3). Наряду с черепами субуральского типа, которых в группе большинство, отмечаются черепа и с иным краниокомплексом. Он описывается более широким и более высоким лицом с некоторой его уплощенностью на верхнем уровне и малым углом выступания носа. Налицо монголоидный или смешанный монголоидноевропеоидный морфотип явно «неместного» происхождения. Вероятно, появление носителей широколицего монголоидного морфокомплекса на Средней Волге связано с переселением тюркоязычных племен болгарского круга и последующих, более поздних перемещений новых групп степного или лесостепного населения. Симптоматично, что в небольшой краниологической серии из Тетюшского 


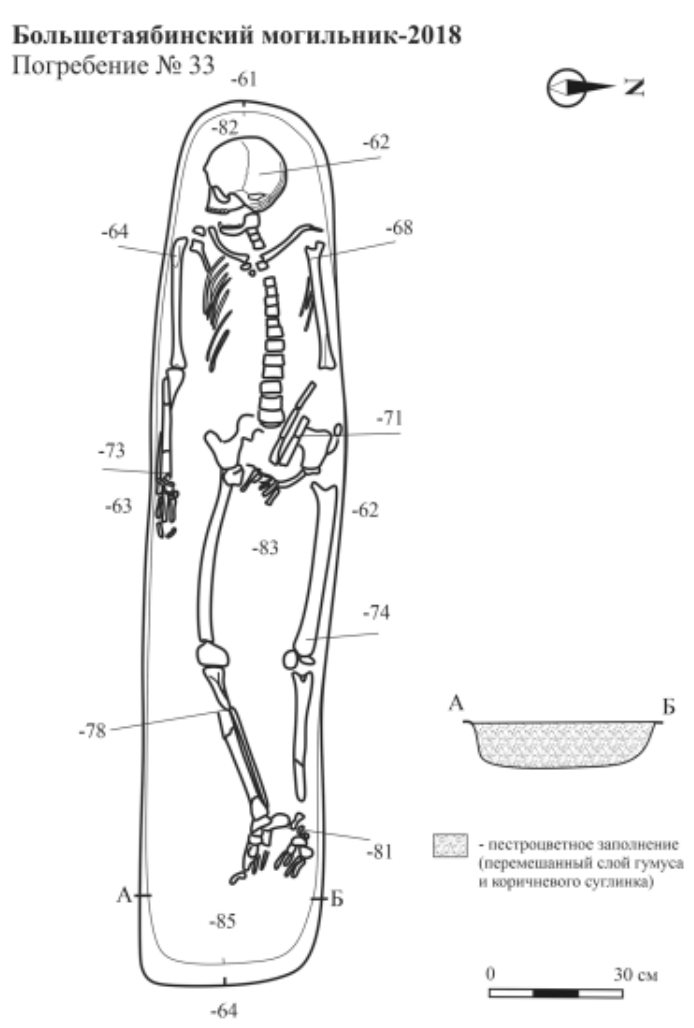

Большетаябинский могильник-2018 Погребение № 35

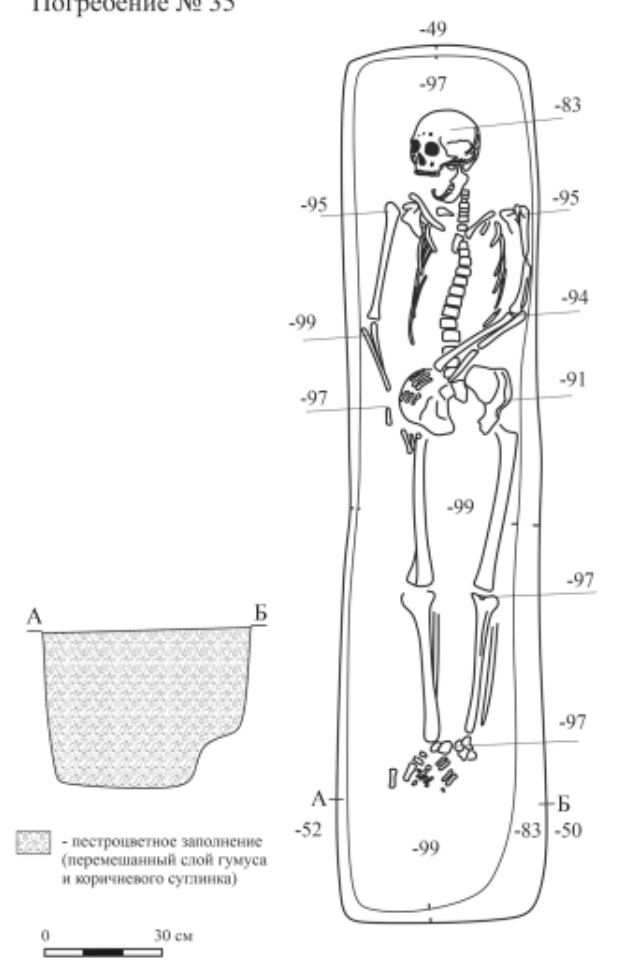

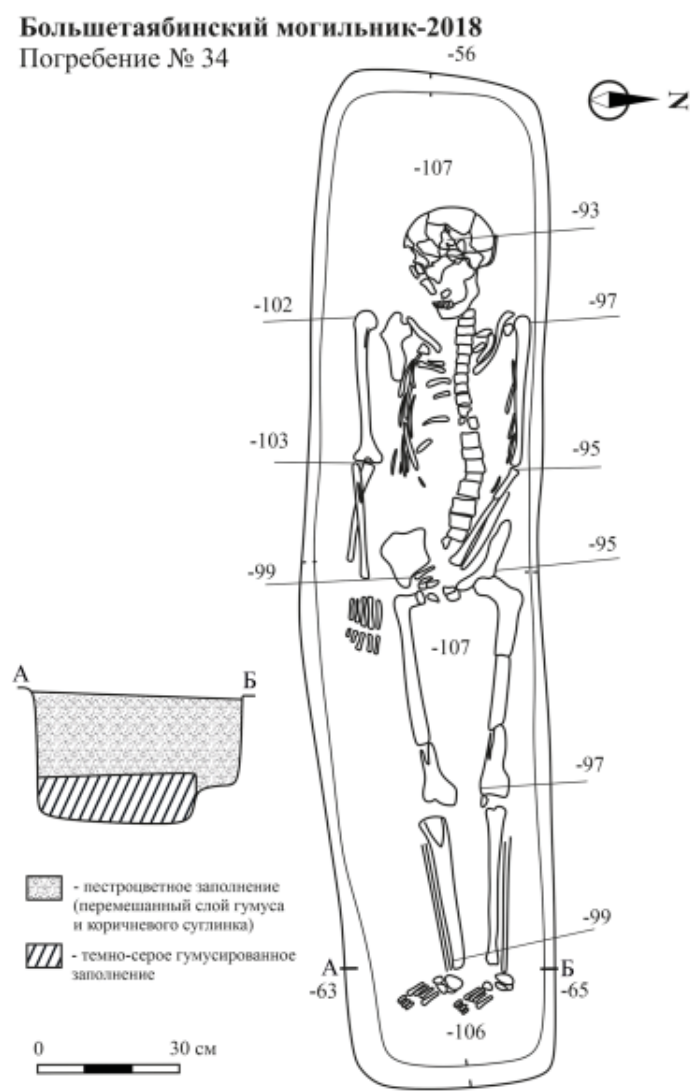

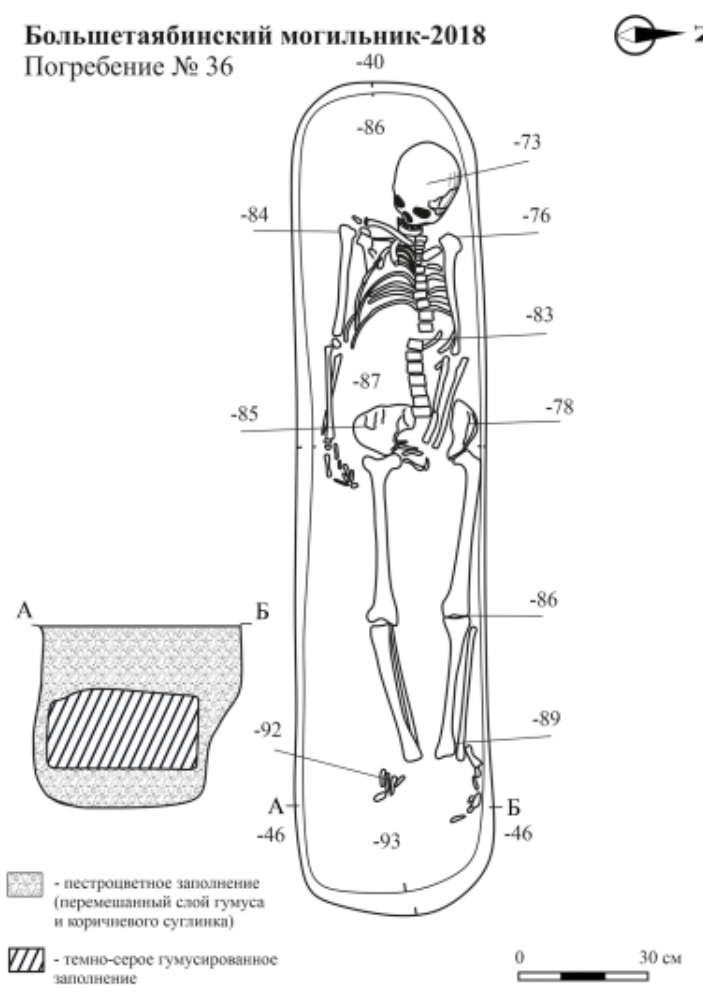

Рис. 5. Планы погребений 33-36 раскопа 2018 г.

Fig. 5. Plans for burials $33-36$ at the excavation of 2018

могильника С.Г. Ефимова также условно выделяет два морфологических компонента: матуризованный (широколицый) и грацильный (узколицый) с более или менее ощутимой монголоидной примесью. Последний высту- пает в серии как основной (Ефимова, 1991, с. 37). Два мужских черепа из мусульманских захоронений на площадке Тетюшского I городища также демонстрируют нам неоднородный в антропологическом отношении состав 
Большетаябинский могильник-2018 Погребение № 37
Большетаябинский могильник-2018

Погребение № 38
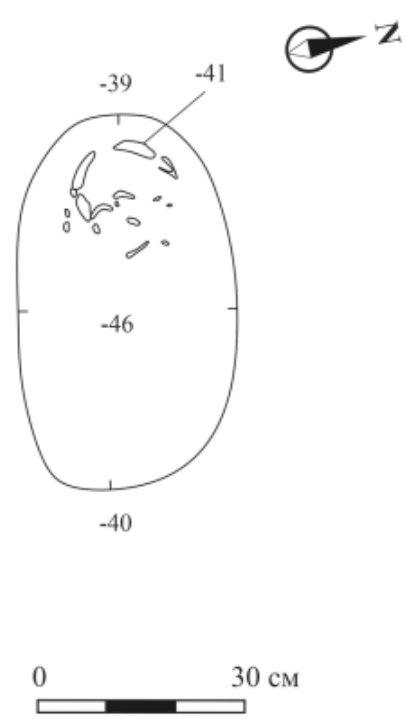

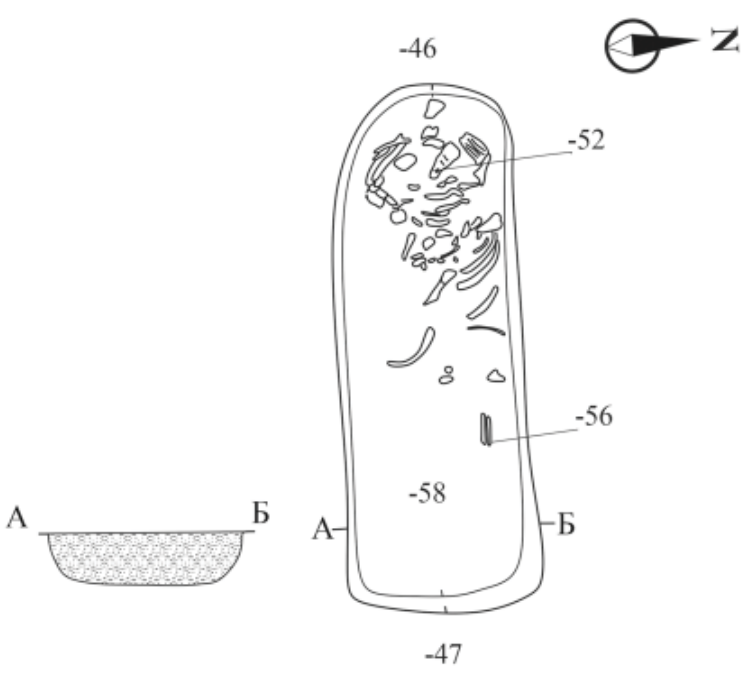

0

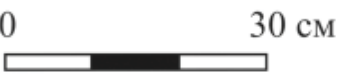

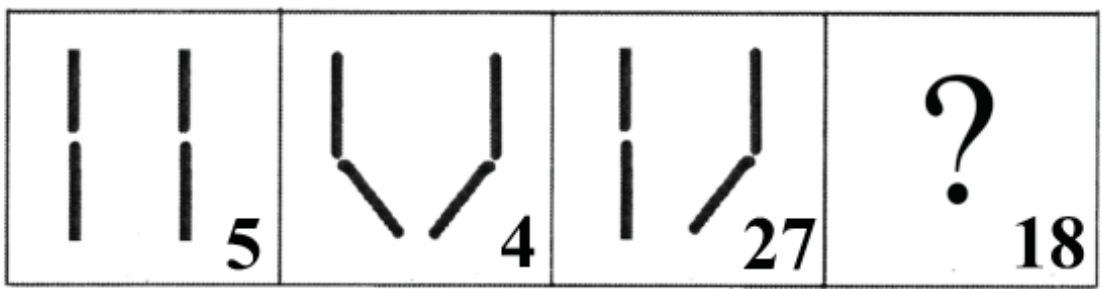

Варианты расположения рук всех погребений могильника

Рис. 6. Планы погребений 33-36 (А) и варианты расположения рук всех погребений могильника (Б)

Fig. 6. Layouts of burials 33-36 (A) and different positions of the hands in all burials of the burial ground (Б)

средневекового предволжского населения. Так, один череп (погребение 1) характеризуется резко европеоидными чертами долихокранного типа, а другой (погребение 4), брахикранный, имеет некоторые монголоидные черты, присущие, вероятнее всего, носителям южносибирского монголоидного типа: низкий свод черепной коробки, широкое и высокое лицо, ослабленная горизонтальная профилировка лица на уровне скул и другие (Газимзянов, 2003, с. 65).

Сравнительный анализ большетаябинской серии черепов с группами, характеризующими физический облик населения Волжской Булгарии, показал, что исследуемая нами серия по своему антропологическому составу отражает общие моменты расогенеза волжских булгар. В его основе лежат широкие метисационные процессы, проходившие между «местным» прикамско-приуральским населением (носителями в основном субуральского типа) и болгарскими или этниче- ски близкими к ним племенами (носителями в основном более широколицего морфокомплекса). Однако наши выводы носят пока лишь предварительный характер, требующий дополнительной аргументации, что невозможно без привлечения нового, более многочисленного антропологического материала.

Примечательно, что выводы, основанные на изучении антропологического материала, коррелируют с археологическими данными. В частности, изучение керамического материала на городище позволяет говорить о проживании на городище носителей различных этнокультурных групп - без труда выделяются угорский, угорско-финский (VII-VIII группы по Т.A. Хлебниковой) и салтово-маяцкий (I группа, часть сосудов с шамотными и растительными примесями) компоненты, вероятна связь некоторых керамических групп с поволжско-финским (мордовским) населением (Михайлов, 2020, с. 75, 99-100). 
Таблииа 2. Средние краниометрические параметры серии черепов

из Большепаябинского некрополя.

Table 2. Average craniometric parameters of a series of skulls from the Bolshaya Tayaba necropolis

\begin{tabular}{|c|c|c|c|c|}
\hline \multirow[t]{2}{*}{ Признак } & \multicolumn{2}{|c|}{ Мужчины } & \multicolumn{2}{|c|}{ Женщины } \\
\hline & $\mathrm{N}$ & $\mathrm{X}$ & $\mathrm{N}$ & $\mathrm{X}$ \\
\hline 1. Продольный диаметр & 5 & 173.8 & 6 & 168.7 \\
\hline 8. Поперечный диаметр & 5 & 143.4 & 7 & 138.3 \\
\hline 17. Высотный диаметр & 5 & 136.0 & 4 & 132.5 \\
\hline 5. Длина основания черепа & 5 & 102.8 & 4 & 99.0 \\
\hline 9. Наименьшая ширина лба & 6 & 94.2 & 6 & 91.2 \\
\hline 40. Длина основания лица & 4 & 96.5 & 3 & 91.7 \\
\hline 45. Скуловой диаметр & 5 & 131.4 & 4 & 121.8 \\
\hline 48. Верхняя высота лица & 5 & 69.8 & 5 & 64.0 \\
\hline 43. Верхняя ширина лица & 6 & 105.8 & 6 & 101.2 \\
\hline 46. Средняя ширина лица & 4 & 95.8 & 4 & 94.8 \\
\hline 55. Высота носа & 5 & 51.4 & 5 & 48.2 \\
\hline 54. Ширина носа & 5 & 25.5 & 5 & 24.3 \\
\hline 51. Ширина орбиты (от мф.) & 5 & 43.8 & 5 & 40.1 \\
\hline 52. Высота орбиты & 5 & 32.9 & 5 & 31.3 \\
\hline 20. Ушная высота & 5 & 115.2 & 5 & 110.0 \\
\hline 77. Назомалярный угол & 6 & 138.8 & 6 & 140.8 \\
\hline Zm. Зигомаксиллярный угол & 3 & 122.1 & 3 & 134.6 \\
\hline SS. Симотическая высота & 4 & 3.9 & 6 & 3.1 \\
\hline SC. Симотическая ширина & 4 & 8.6 & 6 & 7.5 \\
\hline DS. Дакриальная высота & 4 & 10.1 & 5 & 8.4 \\
\hline DC. Дакриальная ширина & 4 & 20.4 & 5 & 20.8 \\
\hline FC. Глубина клыковой ямки & 6 & 4.4 & 5 & 4.5 \\
\hline 32. Угол профиля лба & 5 & 82.0 & 5 & 83.6 \\
\hline 72. Общий лицевой угол & 5 & 86.8 & 3 & 86.0 \\
\hline 74. Альвеолярный угол & 4 & 76.3 & 3 & 73.0 \\
\hline 75(1). Угол носа & 4 & 23.3 & 4 & 22.0 \\
\hline 8:1. Черепной указатель & 6 & 83.1 & 6 & 81.9 \\
\hline 9:8. Лобно-поперечный указатель & 6 & 65.1 & 6 & 66.2 \\
\hline 17:1. Высотно-продольный ук-ль & 5 & 78.3 & 4 & 78.9 \\
\hline 17:8. Высотно-поперечный ук-ль & 4 & 95.2 & 4 & 97.8 \\
\hline 48:45. Верхне-лицевой указатель & 5 & 53.1 & 4 & 52.2 \\
\hline 54:55. Носовой указатель & 5 & 49.8 & 5 & 50.6 \\
\hline 52:51. Орбитный указатель & 5 & 75.5 & 5 & 78.3 \\
\hline SS:SC. Симотический указатель & 4 & 45.4 & 6 & 41.5 \\
\hline DS:DC. Дакриальный указатель & 4 & 49.8 & 5 & 40.5 \\
\hline Надпереносье (1-6) & 7 & 2.2 & 7 & 1.6 \\
\hline Наружный затылочный бугор (0-5) & 6 & 2.4 & 7 & 1.4 \\
\hline Переднее-носовая кость (1-5) & 5 & 3.0 & 6 & 2.8 \\
\hline Форма нижнего края носового отверстия: Antr. - \% & 7 & 57.1 & 7 & 85.8 \\
\hline
\end{tabular}

Таблища 3. Индивидуальные краниометрические параметры черепов из захоронений Большетаябинского некрополя

Table 3. Individual craniometric parameters of skulls from the burials of the Bolshaya Tayaba necropolis

\begin{tabular}{|l|l|l|l|l|l|l|l|l|}
\hline Признак & Погр. 22 & Погр. 23 & Погр. 30 & Погр. 32 & Погр. 33 & Погр. 34 & Погр. 35 & Погр. 36 \\
\hline Пол & Жен. ? & Жен. & Муж. & Жен. & Муж. ? & Муж. ? & Муж. & Жен. \\
\hline Возраст & зрелый & $30-40$ лет & $35-45$ лет & $40-50$ лет & зрелый & зрелый & $25-35$ лет & $20-30$ лет \\
\hline 1. & - & $178.0 ?$ & 183.0 & 162.0 & $180.0 ? ?$ & - & 173.0 & 172.0 \\
\hline 8. & 139.0 & $153.0 ?$ & $136.0 ?$ & 133.0 & $153.0 ? ?$ & - & 154.0 & 140.0 \\
\hline 17. & - & $137.0 ? ?$ & $140.0 ?$ & - & - & - & 145.0 & 130.0 \\
\hline 5. & - & - & $110.0 ?$ & - & - & - & 107.0 & 102.0 \\
\hline 9. & - & 90.0 & 93.0 & 91.0 & 102.0 & - & 92.0 & 95.0 \\
\hline 11. & - & $133.0 ? ?$ & $128.0 ?$ & 121.0 & - & - & 139.0 & 121.0 \\
\hline
\end{tabular}




\begin{tabular}{|c|c|c|c|c|c|c|c|c|}
\hline 40. & - & - & 105.0 & - & - & - & 88.0 & 99.0 \\
\hline 45. & - & 133.0?? & 141.0? & 116.0?? & - & - & 141.0 & 127.0 \\
\hline 48. & - & 66.0 & $79.0 ?$ & - & - & - & 72.0 & 62.0 \\
\hline 47. & - & - & $133.0 ?$ & - & - & - & 122.0 & 108.0 \\
\hline 43. & - & 107.0 & 109.0 & 98.0 & 111.0 & - & 105.0 & 106.0 \\
\hline 46. & - & - & 94.0 & - & - & - & - & 93.0 \\
\hline 55. & - & $52.0 ?$ & $55.0 ?$ & - & - & - & 54.0 & 47.0 \\
\hline 54. & - & $26.0 ?$ & 24.0 & - & $28.0 ?$ & - & 26.5 & 24.0 \\
\hline 51. & - & $40.0 ?$ & $47.0 !$ & 38.0 & - & - & 44.0 & 46.0 \\
\hline 52. & - & $32.0 ?$ & 32.0 & 31.0 & - & - & 35.0 & 32.0 \\
\hline 20. & - & $120.5 ? ?$ & 113.0 & 103.0 & - & - & 119.0 & 112.0 \\
\hline 77. & - & 144.7 & 135.2 & 144.3 & $142.2 ?$ & - & 145.3 & 127.8 \\
\hline $\mathrm{Zm}$. & - & - & 118.2 & - & - & - & - & 132.7 \\
\hline SS. & - & 5.2 & - & 2.2 & - & - & 3.8 & 3.5 \\
\hline SC. & - & 10.0 & - & 6.0 & - & - & 7.8 & 8.2 \\
\hline DS. & - & 10.8 & - & 7.8 & - & - & 5.6 & 5.8 \\
\hline DC. & - & 23.0 & - & 18.2 & - & - & 21.1 & 21.1 \\
\hline Гл. кл.ямки & 4.5 (пр.) & - & 6.5 & - & $1.5 ?$ & - & 3.2 & 4.0 \\
\hline 32. & - & средний & 70.0 & 80.0 & прямой & - & 82.0 & 80.0 \\
\hline 72. & - & - & 84.0 & - & - & - & 95.0 & 82.0 \\
\hline 74. & - & - & $77.0 ?$ & - & - & - & 79.0 & 72.0 \\
\hline $75(5)$. & - & $20.0 ? ?$ & большой & малый & - & - & 20.0 & 20.0 \\
\hline $8: 1$ & - & $85.9 ?$ & $74.3 ?$ & 82.1 & $85.0 ? ?$ & - & 89.0 & 81.4 \\
\hline 17:1. & - & - & $76.5 ?$ & - & - & - & 83.8 & 75.6 \\
\hline 17:8. & - & - & $102.9 ?$ & - & - & - & 94.2 & 92.9 \\
\hline 9:8. & - & $58.8 ?$ & 68.4 & 68.4 & $66.7 ?$ & - & 59.7 & 67.9 \\
\hline $40: 5$. & - & - & 95.5 & - & - & - & 82.2 & 97.1 \\
\hline $48: 45$. & - & - & $56.0 ?$ & - & - & - & 51.1 & 48.8 \\
\hline 54:55. & - & $50.0 ?$ & 43.6 & - & - & - & 49.1 & 51.1 \\
\hline $52: 51$. & - & $80.0 ?$ & 68.1 & 81.6 & - & - & 79.6 & 69.6 \\
\hline SS:SC. & - & 52.0 & - & 36.7 & - & - & 48.7 & 42.7 \\
\hline DS:DC. & - & 46.9 & - & 42.9 & - & - & 26.5 & 27.5 \\
\hline Форма черепа & Эллипсоид & Сфеноид & Овоид & Сфеноид & Пентаг. & Ромбоид & Сфеноид & Ромбоид ? \\
\hline Надп-е (1-6) & 1.0 & 1.5 & 3.0 & 2.0 & - & - & 3.5 & 2.0 \\
\hline Надбр. дуги (1-3) & 1.0 & 1.5 & 2.5 & 1.5 & 1.5 & 1.5 & 2.0 & 1.5 \\
\hline $\begin{array}{l}\text { Зат. бугор } \\
(0-5)\end{array}$ & 1.5 & 1.5 & 3.5 & 1.5 & 2.0 & 3.5 & 2.5 & 1.5 \\
\hline $\begin{array}{l}\text { Сосц. } \\
\text { отросток(1-3) }\end{array}$ & 1.5 & 2.0 & 2.5 & 2.0 & 2.5 & 2.0 & 2.5 & 2.0 \\
\hline $\begin{array}{l}\text { Носовая ость } \\
(1-5)\end{array}$ & 2.0 & 2.0 & 3.0 & - & - & - & 4.0 & 3.5 \\
\hline $\begin{array}{l}\text { Ниж. край гр-го } \\
\text { отв-я }\end{array}$ & Antr. & F.Pr. & \begin{tabular}{|l|} 
Antr./ \\
F.Pr. \\
\end{tabular} & Antr. & Antr./ F.Pr. & Antr. & Antr./ F.Pr. & Antr. \\
\hline
\end{tabular}

\section{Примечания:}

${ }^{1}$ А.П. Смирнов полагал, что восточная ориентировка может быть реминисценцией абашевского погребального обряда бронзового века (Смирнов. 1950. С. 148; Смирнов. 1961. С. 163). Позже это мнение было поддержано Б.В. Каховским (Каховский Б.В. 1985. С. 26). Сейчас подобные представления, высказанные в эпоху идей марризма в археологии представляют лишь историографический интерес.

${ }^{2}$ В 1992 г. Чувашской археологической экспедицией (Б.В. Каховский, В.Ф. Каховский) на самом конце мыса, где располагается Большетаябинский могильник, были найдены «остатки жертвенного кострища... в виде пятна золы и угольков, содержащего обуглившиеся зерна» (Каховский Б.В. 1998. С. 33). Однако должной фиксации кострища проведено не было, его датировка неизвестна, а связь с погребениями не прослежена. Место могильника сейчас используется для отдыха и разведения костров жителями с. Бол. Таяба.

${ }^{3}$ У жителей с. Бол. Таяба сохранилось предание о том, что на могильнике захоронены жители городища Хула, погибшие во время монголо-татарского нашествия [Каховский Б.В. 1985. С. 30].

${ }^{4}$ А.П. Смирнов отметил, что в ходе экспедиции 1948 г. жители с. Бол. Таяба утверждали, что «рядом с разрушенными погребениями находили железные вещи, в частности наконечники стрел» (Смирнов.1950. С. 153).

${ }^{5}$ Под «Южной Чувашией» надо предполагать материалы Татмыш-Югелевского могильника

${ }^{6}$ В опубликованной в 1971 г. статье антрополог В.П. Алексеев в разделе «Краниология чувашей в связи с 
проблемами их происхождения» приводит сопоставление серий «из средневековых предположительно тюркских могильников Приуралья и Поволжья», включив туда и антропологические данные по могильнику «Сють- Сирьми» (Алексеев. 1971. С. 256 (табл. 1), 257 (табл. 2)).

7 Экспедиция 1984 г. не стала учитывать раскоп 1948 г. Нумерация погребений также не была продолжена, а начата заново.

${ }^{8}$ Сделать это достаточно проблематично, т.к. от раскопок 1948 г. сохранилось лишь 5 фотографий расчищенных костяков, в отчете отсутствуют планы захоронений и их описание. Размеры и ориентировка погребений раскопок А.П. Смирнова 1948 г. измерены по общему плану раскопа. В отчете за 1984 г. присутствуют описания, фотографии и планы всех погребений, однако не всегда точно отмечена поза погребенного.

${ }^{9}$ К сожалению, отчет 1948 г. не позволяет проверить позу у 16 погребений, а фотографии и планы из отчета 1984 г. не всегда позволяют оценить легкий поворот корпуса вправо.

\section{ЛИТЕРАТУРА}

Акимова М.С. Палеоантропологические материалы с территории Чувашской АССР // КСИЭ. Вып. 23. М.: АН ССCР, 1955. С. 78-92.

Алексеев В.П. Очерк происхождения тюркских народов Восточной Европы в свете данных краниологии // Вопросы этногенеза тюркоязычных народов Среднего Поволжья. Археология и этнография Татарии. Вып. 1 / Отв. ред. А.Х. Халиков. Казань: Татполиграф, 1971. С. 232-271.

Археологическая карта Чувашской Республики. Т. 3. / Отв. ред. Е.П. Михайлов, Н.С. Березина. Чебоксары: Чувашское книжное изд-во, 2015. 367 с.

Бурханов А.А., Валиев Л.Х., Гайнуллин Р.К., Замалтдинов Р.Р. Археологические исследования в Тетюшском районе в 2003 году (предварительные итоги) // Зеленодольский регион: проблемы истории и культуры. Восток-Запад: диалог культур Евразии (серия «Проблемы истории и археологии»). Вып. 3. / Отв. ред. А.А. Бурханов. Казань: ТГГИ, 2003. С. 54-62.

Газимзянов И.Р. Антропологическая характеристика костяков из захоронений с территории Тетюшского I городища // Зеленодольский регион: проблемы истории и культуры. Восток-Запад: диалог культур Евразии (серия «Проблемы истории и археологии»). Вып. 3. / Отв. ред. А.А. Бурханов. Казань: ТГГИ, 2003. С. 62-69.

Ефимова С.Г. Палеоантропология Поволжья и Приуралья. М.: МГУ, 1991. 95 с.

Кавеев М.M. Некоторые итоги исследования IV Кожаевского селища // Историко-археологическое изучение Поволжья / Отв. ред. Ю.А. Зеленеев. Йошкар-Ола: МарГУ, 1994. С. 94-99.

Каховский Б.В. Исследования Чувашской археологической экспедиции в 1983-1984 гг. // Новые материалы по археологии и этнографии чувашского народа / Отв. ред. В.П. Иванов, В.А. Прохорова. Чебоксары: ЧНИИ, 1985. С. 3-31.

Каховский Б.В. Средневолжский археологический словарь. Учебное пособие. Чебоксары: ЧГПУ, 1998. $151 \mathrm{c}$.

Каховский Б.В., Каховский В.Ф. Археология Среднего Поволжья. Учеб. пос. 2-е изд., доп. Чебоксары: ЧГУ, 1992. 130 с.

Каховский В.Ф. Булгарские памятники на территории Чувашии// История исследования археологических памятников в Чувашском Поволжье и материалы по антропологии чувашей. Чебоксары: ЧГИГН, 1995. С. 3-33.

Каховский В.Ф., Смирнов А.П. Памятники средневековья Чувашского Поволжья// Городище Хулаш и памятники средневековья Чувашского Поволжья. Чебоксары: ЧНИИ ЯЛИЭ, 1972. С. 115-166.

Краснов Ю.А. Проблема происхождения чувашского народа в свете археологических данных // СА. 1974. № 3. C. 112-124.

Михайлов Е.П. Отчет об археологических раскопках Большетаябинского городища и могильника в Яльчикском районе Чувашской Республики в 2018 г. по Открытому листу № 534 от 23 мая 2018 г. Т. 1. 274 с. Т. 2.132 илл.

Смирнов А.П. Исследования городища и могильника золотоордынской эпохи у села Б. Таяба Чувашской АССР// Записки ЧНИИ ЯЛИ. Вып. IV. Чебоксары, 1950. С. 131-153.

Фахрутдинов Р.Г. О степени заселенности булгарами территории современной Чувашской АССР// Вопросы этногенеза тюркоязычных народов Среднего Поволжья. Археология и этнография Татарии. Вып. 1 / Отв. ред. А.Х. Халиков. Казань: Татполиграф, 1971. С. 175-201.

Халикова Е.A. Мусульманские некрополи Волжской Булгарии Х - начала XIII в. Казань: КГУ, 1986. $160 \mathrm{c}$.

Яблонский Л.Т. Некрополи Болгара // Город Болгар: Очерки ремесленной деятельности / Отв. ред. Г.А. Федоров-Давыдов. М.: Наука, 1987. С. 124-142. 


\section{Информация об авторах}

Березина Наталия Степановна, кандидат исторических наук, ведущий научный сотрудник, Чувашский государственный институт гуманитарных наук (г. Чебоксары, Россия); terra3@inbox.ru

Березин Александр Юрьевич, научный сотрудник, Чувашский государственный институт гуманитарных наук (г. Чебоксары, Россия); terra3@inbox.ru

Газимзянов Ильгизар Равильевич, кандидат исторических наук, старший научный сотрудник, Казанский (Приволжский) федеральный университет (г. Казань, Россия); g-ilgizar@yandex.ru

Михайлов Евгений Петрович, старший научный сотрудник, Чувашский государственный институт гуманитарных наук (г. Чебоксары, Россия); mihaylov.evgeniy.1958@mail.ru

Мясников Николай Станиславович, кандидат исторических наук, старший научный сотрудник, Чувашский государственный институт гуманитарных наук (г. Чебоксары, Россия); myasnikovn1988@ gmail.com

Хамзин Радион Наилевич, научный сотрудник, Институт археологии им. А.Х. Халикова АН РТ (г. Казань, Россия); khrn80@yandex.ru

\section{REFERENCES}

Akimova, M. S. 1955. In Kratkie soobshcheniia Instituta etnografii (Concise Bulletins of the Institute of Ethnography) 23. Moscow: Academy of Sciences of the USSR, 78-92 (in Russian).

Alekseev, V. P. 1971. In Khalikov, A. Kh. (ed.). Voprosy etnogeneza tiurkoiazychnykh narodov Srednego Povolzh 'ia (The Issues on Ethnic Genesis of the Turkic-speaking People of the Middle Volga Region). Series: Arkheologiia i etnografiia Tatarii (Archaeology and Ethnography of Tataria) 1. Kazan: "Tatpoligraf" Publ., 232-271 (in Russian).

Mikhailov, E. P., Berezina, N. S. (eds.). 2015. Arkheologicheskaia karta Chuvashskoi Respubliki (Archaeological Map of the Chuvash Republic) 3. Cheboksary: "Chuvashskoe knizhnoe izdatel'stvo" Publ. (in Russian).

Burkhanov, A. A., Valiev, L. Kh., Gainullin, R. K. 2003. In Burkhanov, A. A. (ed.). Zelenodol'skii region: problemy istorii i kul'tury. Vostok-Zapad: dialog kul'tur Evrazii (Zelenodolsk Region: Issues of History and Culture. East-West: Dialogue of Eurasian Cultures). Series: Problemy istorii i arkheologii (Issues of History and Archaelogy) 3. Kazan: Tatar State Institute for Humanities, 54-62 (in Russian).

Gazimzyanov, I. R. 2003. In Burkhanov, A. A. (ed.). Zelenodol'skii region: problemy istorii i kul'tury. Vostok-Zapad: dialog kul'tur Evrazii (Zelenodolsk Region: Issues of History and Culture. East-West: Dialogue of Eurasian Cultures). Series: Problemy istorii i arkheologii (Issues of History and Archaelogy) 3. Kazan: Tatar State Institute for Humanities, 62-69 (in Russian).

Efimova, S. G. 1991. Paleoantropologiia Povolzh'ia i Priural'ia (Paleoanthropology of the Volga Region and the Urals). Moscow: Moscow State University Publ. (in Russian).

Kaveev, M. M. 1994. In Zeleneev, Yu. A. (ed.). Istoriko-arkheologicheskoe izuchenie Povolzh'ia (Historical and Archaeological Study of the Volga Region). Yoshkar-Ola: Mari State University, 94-99 (in Russian).

Kakhovskii, B. V. 1985. In Ivanov, V. P., Prokhorova, V. A. (eds.). Novye materialy po arkheologii $i$ etnografii chuvashskogo naroda (Recent Materials on the Archaeology and Ethnography of the Chuvash People). Cheboksary: Chuvash Research Institute, 3-31 (in Russian).

Kakhovskii, B. V. 1998. Srednevolzhskii arkheologicheskii slovar' (The Middle Volga Archaeological Dictionary). Cheboksary: Chuvash State Pedagogical Institute (in Russian).

Kakhovskii, B. V., Kakhovskii, V. F. 1992. Arkheologiia Srednego Povolzh'ia. Uchebnoe posobie (Archaeology of the Middle Volga Area: Educational book). Cheboksary: Chuvashia State University (in Russian).

Kakhovskii, B. V. 1995. In Istoriia issledovaniia arkheologicheskikh pamiatnikovv Chuvashskom Povolzh'e $i$ materialy po antropologii chuvashei (History of the Study of Archaeological Sites in the Chuvash Volga Region and Materials on the Anthropology of the Chuvash). Cheboksary: Chuvash State Research Institute for Humanities, 3-33 (in Russian).

Kakhovskii, V. F., Smirnov, A. P. 1972. In Prokhorova, V. A. (ed.). Gorodishche Khulash i pamjatniki srednevekov'ia Chuvashskogo Povolzh'ia (Khulash Hillfort and the Medieval Sites of the Chuvash Volga Region). Cheboksary: Chuvashia Institute of Language, Literature, History, and Economy affiliated to the Council of Ministers of Chuvash ASSR, 115-166 (in Russian)

Krasnov, Yu. A. 1974. In Sovetskaia Arkheologiia (Soviet Archaeology) (3), 112-124 (in Russian).

Mikhailov, E. P. Otchet ob arkheologicheskikh raskopkakh Bol'shetaiabinskogo gorodishcha i mogil'nika v Ial'chikskom raione Chuvashskoi Respubliki v 2018 g. po Otkrytomu listu № 534 ot 23 maia 2018 g. (Report on the Archaeological Excavations of the Bolshaya Tayaba Hillfort and Burial Ground in the Yalchiksky District 
of the Chuvash Republic in 2018 According to the Permit Document No. 534 dated May 23, 2018.) 1 (in Russian).

Smirnov, A. P. 1950. In Zapiski Chuvashskogo instituta iazyka, literatury, istorii i ekonomiki pri Sovete Ministrov Chuvashskoi ASSR (Proccedings of the Chuvashia Institute of Language, Literature, History, and Economy affiliated to the Council of Ministers of Chuvashian ASSR). IV. Cheboksary, 131-153.

Fakhrutdinov, R. G. 1971. In Khalikov, A. Kh. (ed.). Voprosy etnogeneza tiurkoiazychnykh narodov Srednego Povolzh'ia (The Issues on Ethnic Genesis of the Turkic-speaking People of the Middle Volga Region). Series: Arkheologiia i etnografiia Tatarii (Archaeology and Ethnography of Tataria) 1. Kazan: "Tatpoligraf" Publ., 175-201 (in Russian).

Khalikova, E. A. 1986. Musul'manskie nekropoli Volzhskoi Bulgarii X - nachala XIII vv. (Muslim Necropolises in Volga Bulgaria in 10 $0^{\text {th }}$ - early $13^{\text {th }}$ Centuries). Kazan: Kazan State University (in Russian).

Yablonsky, L. T. 1988. In Fedorov-Davydov, G. A. (ed.). Gorod Bolgar. Ocherki remeslennoi deiatel'nosti (Town of Bolgar. Essays on Handicrafts). Moscow: "Nauka" Publ., 124-142. (in Russian).

\section{About the Athours:}

Berezina Natalia S. Candidate of Historical Sciences. Chuvash State Institute for Humanities. Moskovsky Av., 29, corp. 1, Cheboksary, 428015, Russian Federation; terra3@inbox.ru

Berezin Aleksandr Yu. Chuvash State Institute for Humanities. Moskovsky Av., 29, corp. 1, Cheboksary, 428015, Russian Federation; terra3@inbox.ru

Gazimzyanov Ilgizar R. Candidate of Historical Sciences, Kazan (Volga Region) Federal University. Kremlyovskaya St., 18, Kazan, 420000, the Republic of Tatarstan, Russian Federation; g-ilgizar@yandex.ru

Mikhailov Evgenii P., Chuvash State Institute for Humanities. Moskovsky Av., 29, corp. 1, Cheboksary, 428015, Russian Federation; mihaylov.evgeniy.1958@mail.ru

Myasnikov Nikolay S. Candidate of Historical Sciences. Chuvash State Institute for Humanities. Moskovsky Av., 29, corp. 1, Cheboksary, 428015, Russian Federation; myasnikovn1988@gmail.com

Khamzin Radion N., Institute of Archaeology named after A.Kh. Khalikov, Academy of Sciences of the Republic of Tatarstan. Butlerov St., 30, Kazan, 420012, Republic of Tatarstan, Russian Federation; khrn80@ yandex.ru

Статья поступила в журнал 01.04.2021 г. Статья принята к публикации 01.04.2021 г. Авторы внесли равноценный вклад в работу. 